\title{
SLOVAK AIRPORTS AS PROFIT/LOSS MAKING ENTITIES: CONSEQUENCES FOR TRANSPORT POLICIES
}

\author{
Alena Novák Sedláčková \\ University of Žilina, Slovakia \\ Denisa Švecová \\ University of Žilina, Slovakia \\ Anna Tomová \\ University of Žilina, Slovakia
}

Received: 7 October 2019. Revision received: 30 October 2019. Accepted: 5 December 2019

\begin{abstract}
Regional airports in the European Union have been studied in several papers so far, however, not delivering a lot of knowledge of airports as profit/loss making entities. In the paper, we focus on the Slovak airports which are typical representatives of regional airports in the EU. As there is the knowledge gap in the field of airports in newer member countries of the EU, we explain the specific socio-economic context of the airports in the Slovak Republic against a background of their financial ratios. Our findings are suggestive of the need to set a clear dividing line and interface between national airport policies of member countries of the EU and the EU common airport policy.
\end{abstract}

Key Words: regional airports, financial analysis, profitability, regions, transport policy.

JEL Classification: L 93, H 54

\section{Introduction}

It is without any doubt that airport infrastructure and services are inevitable for the economic and social progress of the European Union. Airports deliver not only connectivity, but they also bring many social and economic impacts for surrounding regions. Airports are important stimulators and catalysts of regional economic growth and development (Kazda et al., 2017). The development of particular regions located in the EU member states is intended to establish a strong unified territory that would be coinhabited by different communities. On the other hand, the harmonious growth of the entire EU is guaranteed by the realization of the regional cohesion policy concerning member states and their regions (Grabowska, 2008). The airports within the EU are miscellaneous as is the case of other aviation markets in the world. An Aviation Strategy for Europe of 2015 stated "Airport connectivity in Europe varies significantly between major hubs on the one hand offering hundreds of destinations and small regional airports on the other with only a few... " (European Commission, 2015). While hub airports in the EU may exploit economies of scale, many regional airports in the EU suffer from diseconomies of being too small. The problem of operation and profitability of regional airports concerns most EU countries as well as airports on other continents (Červinka\&Matušková, 2018). The grid of regional airports within the EU is still the residual of historically fragmented aviation markets of European countries, what resulted in the situation when many regional airports in the EU have overlapped catchment areas 
under the conditions of the EU's liberalised single aviation market. Such regional airports compete each other within the commonly shared catchment areas, what negatively impacts on the utilisation of their capacities and subsequently on their profitability and funding. This was expressed by the European Commission in the Aviation Guidelines of 2014 for state aid to airports and start-up to airlines: “...the Commission will have doubts as to the prospects for an unprofitable airport to achieve full operating cost coverage at the end of the transitional period (2024), if another airport is located in the same catchment area" (European Commission, 2014). This points to the over-capacities of regional airports within the EU in several European regions. In 2017, the European Parliament even called for a long-term strategy "to address, on the one hand, the surplus of loss-making airports in regions where other modes of transport are available and on the other hand, the contribution of secondary airports to the development, competitiveness and integration of EU regions ..." (European Parliament, 2017). The elaboration of such long-term strategy will not be possible without disposing of comprehensive data on the EU's regional airports and understanding their specific socioeconomic context. For EU common aviation market is the quality of the business environment a key factor in the economic development of countries, as it is of a great importance for the growth of the economy's competitiveness and also for its future and sustainable economic growth (Čepel, 2019).

In this paper, we shall investigate airports in the Slovak Republic as profit/loss making entities in a broader socio-economic context, considering also the issues of transport policy. According to the rules of state aid to airports and start-up aid to airlines issued by the European Commission in 2014, all airports with international operation in Slovakia fall under the category of European regional airports as their performance is below 3 million passengers per year. This fact even relates to the capital airport of the Slovak Republic - Bratislava Airport. This makes the Slovak Republic unique as a country of (only) regional airports. After a brief review of the respective scientific literature on the economics of regional airports, we explain the methodology and the aim of our paper. Upon the quantitative results interlinked with the specific socio-economic context of Slovak airports, we discuss consequences for national transport policy of the Slovak Republic and the Common Transport Policy of the EU as well. Thus, the main aim of our paper is to interlink a broader socio-economic context in which Slovak airports operate with the results of ex-post financial analysis and bring ideas how to improve and interconnect national transport policies with the transport policy of the EU.

\section{Literature review on the economics of regional airports}

Current knowledge on regional airports' economics, originating from different world regions and countries, reveals different roots of regional airports' inefficiencies. Abbott (2015) found that the larger New Zealand's airports after structural reform were more efficient than the smaller ones. Barros et al. (2013) investigated French regional airports, bringing the finding that the airports maintained or increased their efficiency after regionalization, thus they proved how the upgrade of managerial procedures in airports may help to achieve efficiency aims. Lian and Ronnevik (2011) dealt with the traffic leakages from regional airports in Norway, mainly in the leisure segment caused by lower air fares and more convenient air services from bigger airports. Similarly, Cahill et al. (2017) stated that the Dublin Airport Authority has effectively faced very limited competition from regional airports. Dobruszkes et al. (2017) confirmed that low-cost 
carriers in Europe and US which were traditional customers for many regional airports tend to increase their operation from major airports while decreasing or cancelling the operation from regional airports. Graham (2013) analysed several issues in the low-cost carrier and airport relationship, stating that in the long-term this relationship need not to be beneficial for airports. Halpern and Graham (2016) found that after the expansion of regional airports due to the expansion of low-cost carriers, many regional airports in the UK recorded decreased profits caused by the reduction of low-cost traffic. Fragoudaki et al. (2017) evaluated the operating efficiency and productivity changes of the Greek airports between 2010 and 2014, stating that overall airport efficiency and productivity improved in time, mainly due to exogenous factors such as international tourism growth. Adler et al. (2013) benchmarked 85 small European airports in several member countries of the European Union, using DEA methodology, and they argued that managerial efficiency contributes to social welfare by minimizing financial losses.

The presented review of scientific literature in the field points to miscellaneous reasons why regional airports may suffer from inefficiencies - insufficient size, the processes of commercialisation, privatisation and regionalisation, competition status, vertical relationship with low-cost carriers etc. The review also demonstrated that European economic research of regional airports was predominantly focused on older member countries in the EU, neglecting thus regional airports in newer member countries of the EU and, eventually, their specific context.

\section{Methodology and aim}

To help in the filling the gap in the knowledge of regional airports in newer member countries of the EU, we decided to explain specific socio-economic context of the airports in the Slovak Republic against a background of their financial ratios. The quantitative part of our approach to (in)efficiency of Slovak (regional) airports differs from the above-mentioned scientific literature as we applied the standard tools of financial analysis (ex-post). Such approach may be reasoned by the commercialisation of regional airports which is in progress in Europe. Further argument for our approach may be found in the ambition of the European Commission expressed in the guidelines for state aid to airports and start-up aid to airlines: "At the end of the transitional period, airports should no longer be granted operating aid and they should finance their operations from their own sources" (European Commission, 2014). The approach we applied may be also supported by Adler et al.'s (2013) statement about how managerial efficiency of regional airports contributes to social welfare. We used the ratios of liquidity, the ratios of capital structure and three ratios of profitability (ROA, ROE and ROS). Our analysis covered 2013 - 2017 years. ${ }^{1}$ Thus, the Slovak airports were investigated as any other business which cannot survive in the long-term if it is not capable to generate profit (Bartošová \& Král', 2017). ${ }^{2}$ When computing the ratios, we followed the ratio's concept as it was recommended in Zalai et al. (2013). In the explanation of socio-economic context, we focused on the performance of Slovak airports

\footnotetext{
${ }^{1}$ The period analysed covers years before the new state aid rules to airports in the EU were issued in 2014 and years after as well. The data for financial analyses were taken from finstat.sk database.

${ }^{2}$ Starting from 2015, i.e. after the Aviation Guidelines 2014 were issued by the European Commission, the Slovak Republic decided to contribute to airports' funding using only the instrument of so-called "performances for state". These performances are represented by activities and services which airports perform on behalf of state (security of airports, emergency services, and firefighting services).
} 
expressed in the number of handled passengers (the size parameter), the evolution of governance and ownership, the competition status (both intermodal and intramodal). When identifying the competing airports which share the same catchment areas with Slovak airports, we used the strict perimeter of $100 \mathrm{~km}$.

\section{Results}

\subsection{Specific socio-economic context of Slovak airports}

The Slovak Republic is a small country $(49,035 \mathrm{~km} 2)$ in which more than five million inhabitants live. Moreover, the Slovak Republic is an inland country with rugged topography, however, with a high density of roads $\left(363 \mathrm{~km}\right.$ per $\left.1,000 \mathrm{~km}^{2}\right)$ and rails $(7.5$ $\mathrm{km}$ per $100 \mathrm{~km}^{2}$ ) what predetermines the potential of demand for domestic air services offered from the Slovak airports. From the point of view of the airport's infrastructure supply, the country has six airports which are designed for civil public international commercial operation (Table 1).

Table 1 The Slovak airports - basic information

\begin{tabular}{|l|c|c|c|c|c|}
\hline \multicolumn{1}{|c|}{ Airport } & $\begin{array}{c}\text { ICAO code } \\
\text { /IATA code }\end{array}$ & $\begin{array}{c}\text { Elevation/Reference } \\
\text { temperature }\end{array}$ & $\begin{array}{c}\text { Distance } \\
\text { from the } \\
\text { city } \\
\text { center }\end{array}$ & $\begin{array}{c}\text { Distance } \\
\text { from } \\
\text { Bratislava }\end{array}$ & $\begin{array}{c}\text { RWY system; RWY } \\
\text { dimensions (length x } \\
\text { width) }\end{array}$ \\
\hline Bratislava & LZIB/BTS & $132 \mathrm{~m} / 28.1^{\circ} \mathrm{C}$ & $10 \mathrm{~km}$ & - & $\begin{array}{c}04 / 22 ; 2,900 \mathrm{~m} \times 60 \mathrm{~m} \\
13 / 31 ; 3,190 \mathrm{~m} \times 45 \mathrm{~m}\end{array}$ \\
\hline Košice & LZKZ/KSC & $230 \mathrm{~m} / 26.4{ }^{\circ} \mathrm{C}$ & $6 \mathrm{~km}$ & $390 \mathrm{~km}$ & $01 / 19 ; 3,100 \mathrm{~m} \times 45 \mathrm{~m}$ \\
\hline Sliač & LZSL/SLD & $318 \mathrm{~m} / 26.8^{\circ} \mathrm{C}$ & $3.5 \mathrm{~km}$ & $190 \mathrm{~km}$ & $18 / 36 ; 2,400 \mathrm{~m} \times 57 \mathrm{~m}$ \\
\hline Žilina & LZZI/ILZ & $311 \mathrm{~m} / 25.6^{\circ} \mathrm{C}$ & $12 \mathrm{~km}$ & $180 \mathrm{~km}$ & $\begin{array}{c}06 / 24 ; 1,150 \mathrm{~m} \times 30 \mathrm{~m} \\
06 / 24 * ; 1,130 \mathrm{~m} \times 45 \mathrm{~m}\end{array}$ \\
\hline $\begin{array}{l}\text { Poprad- } \\
\text { Tatry }\end{array}$ & LZTT/TAT & $718 \mathrm{~m} / 23.0^{\circ} \mathrm{C}$ & $4.3 \mathrm{~km}$ & $313 \mathrm{~km}$ & $09 / 27 ; 2,600 \mathrm{~m} \times 45 \mathrm{~m}$ \\
& & & & & $07 \mathrm{~L} / 25 \mathrm{R} ; 760 \mathrm{~m} \times 35 \mathrm{~m}$ \\
& & $166 \mathrm{~m} / 28.3^{\circ} \mathrm{C}$ & $3.5 \mathrm{~km}$ & $90 \mathrm{~km}$ & $01 / 19 ; 2,000 \mathrm{~m} \times 30 \mathrm{~m}$ \\
\hline Piešt'any & LZPP/PZY & & & & \\
\hline
\end{tabular}

Source: Annual reports of the airports Bratislava, Košice, Sliač, Žilina, Poprad Tatry, Pieštany; AIP SR Part 3, AD: LZZI, LZSL, LZIB, LZKE, LZPT, LZTT, 2018.

All airports in Slovakia fall under the category of regional airports, not exceeding the threshold of three million handled (transported) passengers per year. Four of the airports belong to the category of very small regional airports (Žilina, Sliač, Piešt'any, PopradTatry) as Fig. 1 depicts ${ }^{3}$.

\footnotetext{
3 The threshold for the category of small regional airports was set by the European Commission by the volume of 200000 passengers handled by an airport per year.
} 
Figure 1 The number of passengers transported by the airports in the Slovak Republic $2013-\mathbf{2 0 1 8}^{4}$

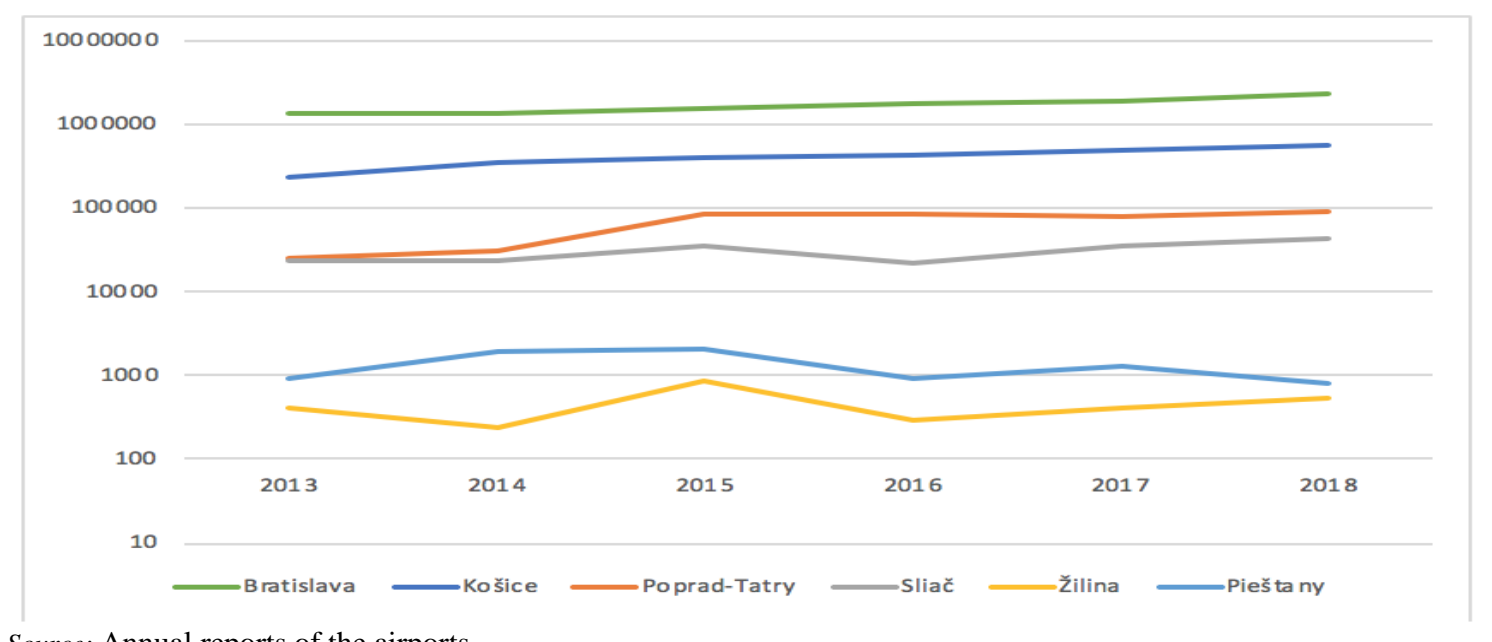

Source: Annual reports of the airports.

Discussing the context of the Slovak airports in terms of the respective catchment areas, the number of directly competing airports with Slovak airports is significant if we do not neglect airports abroad as Fig. 2 depicts ${ }^{5}$.

Figure 2 Airports directly competing with Slovak airports

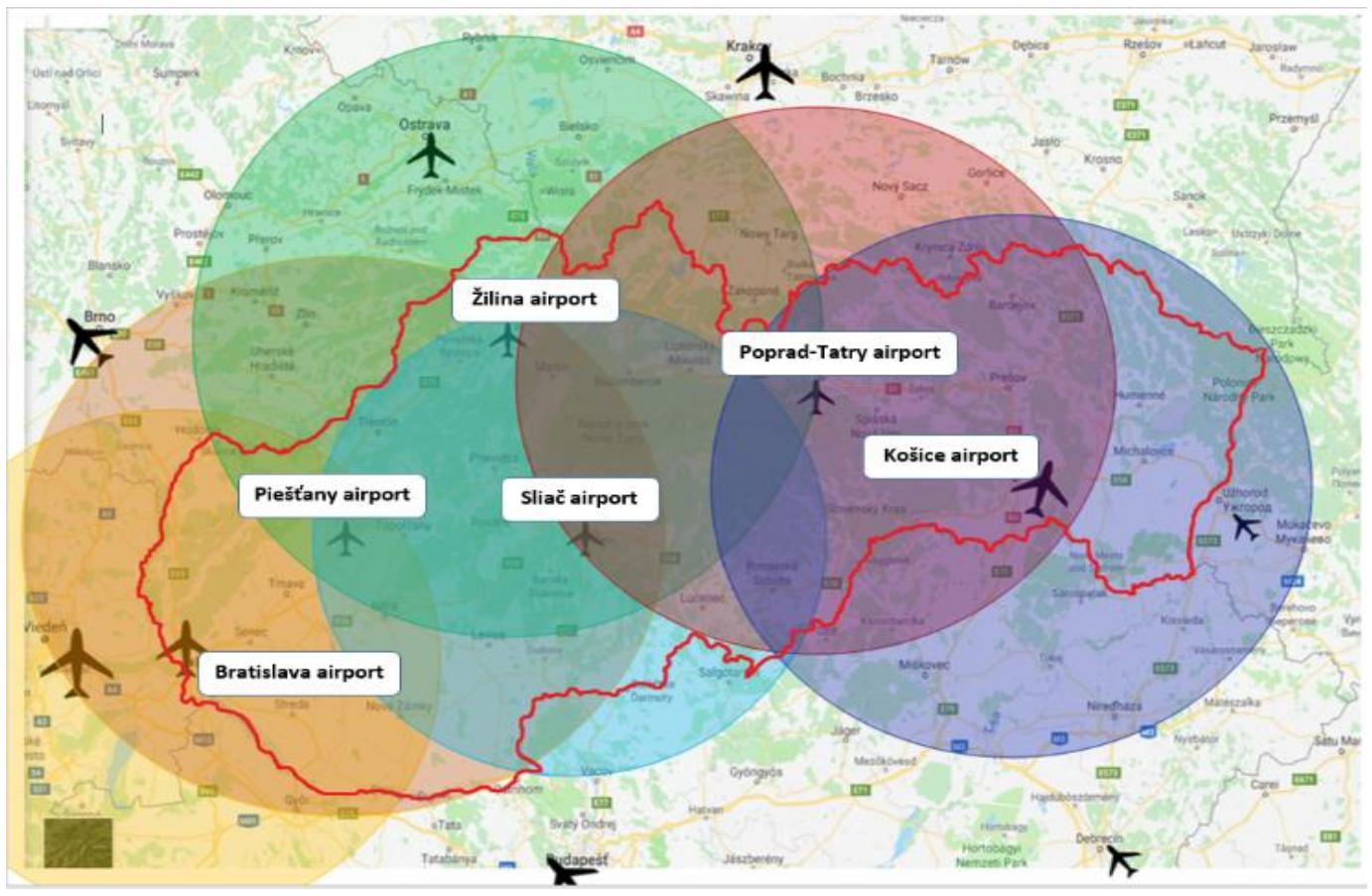

Source:authors.

Fig. 2 shows the density of competing airports with the Slovak airports within the same (i.e. partially overlapped) catchment areas. Intentionally, the areas were set very

\footnotetext{
4 The performance of Žilina airport was too small to be clearly indicated in Figure 1 (1,712 passengers in 2012, 298 passengers in 2016).

${ }^{5}$ In this regard, it ought to be noted that there are still documents in which the catchment areas of the Slovak airports have been set within the political borders of the Slovak Republic, ignoring thus the reality of the EU's common aviation market with air services (Reiff, 2007).
} 
rigorously, using the perimeter $100 \mathrm{~km}$. Moreover, the co-existence of two capital airports in the commonly shared catchment area (Vienna Airport and Bratislava Airport) is unique within the European Union what makes the issues of the Slovak airports yet more intricate.

With the exemption of capital airport, the airports in the Slovak Republic have relatively small catchment areas in terms of population, they with strong competition of rails and roads what predetermines the volumes of outbound air traffic. Moreover, there are not considerable in-built demand's stabilizers in the Slovak Republic which would generate permanent extensive inbound air traffic, although there is at least some potential due to the attractiveness of the Slovak Republic in tourism.

In the past, being a part of the transport infrastructure within Czechoslovakia, Slovak airports were characterised by governance structures which were typical for the directive economic regime of socialism. In principle, despite many changes realized during this period, Czechoslovak airports belonged to so-called traditional airport's governance and ownership model (Tomová et al., 2017). Two years before splitting Czechoslovakia, the governance model of Slovak airports was restructured, and the Slovak Airport Authority was established in 1991, being an allowance entity. The Slovak Airport Authority disposed of some autonomy in economic issues and represented an inter-stage in the subsequent process of the Slovak airports' corporatisation. At the present time, all the above-mentioned Slovak airports are joint stock companies formed in 2005 in accordance with the Act No. 136/2004 Coll. On Airport Companies and on Amendments to the Act No. 143/1998 Coll. On Civil Aviation (Aviation Act) (Novák \& Novák Sedláčková, 2010). The Ministry of Transport and Construction of the Slovak Republic on behalf of the Slovak Republic has a stake in the ownership of all the abovementioned airports:

- $100 \%$ at Bratislava Airport and Sliač Airport,

- $99.535 \%$ at Žilina Airport,

- $97.61 \%$ at Poprad-Tatry Airport,

- $34 \%$ at Košice Airport,

- and $20.65 \%$ at Piešt'any Airport ${ }^{6}$.

The public ownership of civil international airports prevails in the Slovak Republic, as the only Košice Airport was partially privatised. After completing the privatization process in 2006, $66 \%$ of the shares of Košice Airport were taken over by Vienna International Airport which shares the same catchment area with Bratislava Airport - the capital airport of Slovakia ${ }^{7}$. In general, Slovak airports went through miscellaneous governance and ownership's changes. Thus, Slovakia experienced a successful and realized airport privatisation (Košice Airport), but also unsuccessful and not realized airport privatisations (Bratislava Airport). There were two attempts to privatise Bratislava capital airport, the first attempt planned to use the divesture of assets, the further attempt assumed the privatisation of Bratislava Airport through a long-term concession, i.e. indirectly. As a part of corporatisation, Slovak airports experienced the decentralisation of airport's public ownership, however also the recentralisation of previously decentralized airport's public ownership of Žilina Airport. And moreover, it was decided that Žilina Airport will be again partially decentralised (regionalized) in

\footnotetext{
${ }^{6}$ As a part of regionalisation, several regions participate in the ownership of several airports in Slovakia.

7 There were two attempts to privatise Bratislava Airport, both were unsuccessful due to political turbulences on the Slovak domestic political scene. The third attempt to privatise bratislava Airport is being prepared at the present.
} 
2020. All the facts fully coincide with the varicoloured mosaics of the European Union's airports as whole, European airports are very miscellaneous and diverse in terms of governance and ownership (Copenhagen Economics, 2012). On the other hand, the frequentness of these changes directed at Slovak airports as well as the reverse nature of the changes in several cases may indicate the absence of a long-term vision at national level what to do with Slovak airports, respecting simultaneously the reality of single aviation market with liberalised air services within the EU. In Slovak republic were many different and mutually contradictory factors be taken into account in the strategic decisions of airport managers (Belas et al., 2018, Dobrovič et al., 2019).

In summary, all civil international airports in the Slovak Republic cope with strong intramodal competition due to the existence of neighbouring airports, airports abroad including. They also rival intermodally, due to the competition of rails and roads in Slovakia and in the surrounding regions. All Slovak airports suffer from being small or too small and they experienced numerous changes aimed at their governance and ownership configuration.

\subsection{Slovak airports as profit/loss making entities}

The results of ex-post financial analysis of Slovak airports are presented in Table 2.

Table 2 The Slovak Airports' indicators of ex-post financial analyses 2013 - 2017

\begin{tabular}{|c|c|c|c|c|c|c|c|}
\hline & & $\begin{array}{c}\text { Bratislava } \\
\text { airport }\end{array}$ & $\begin{array}{l}\text { Košice } \\
\text { airport }\end{array}$ & $\begin{array}{c}\text { Piešt'any } \\
\text { airport }\end{array}$ & $\begin{array}{c}\text { Sliač } \\
\text { airport }\end{array}$ & $\begin{array}{c}\text { Žilina } \\
\text { airport }\end{array}$ & $\begin{array}{c}\text { Poprad- } \\
\text { Tatry } \\
\text { airport }\end{array}$ \\
\hline & 2017 & $2.51: 1$ & 18.63:1 & $0.16: 1$ & $2.81: 1$ & $0.12: 1$ & $0.17: 1$ \\
\hline & 2016 & $1.79: 1$ & $17.77: 1$ & $0.14: 1$ & $2.43: 1$ & $0.02: 1$ & 1.03:1 \\
\hline Liquidity I. & 2015 & $2.37: 1$ & 15.44:1 & $0.30: 1$ & $2.28: 1$ & $0.04: 1$ & $4.47: 1$ \\
\hline (EUF & 2014 & $1.88: 1$ & 19.52:1 & $0.28: 1$ & 1.99:1 & $0.74: 1$ & $6.22: 1$ \\
\hline & 2013 & $1.17: 1$ & $23.00: 1$ & $0.38: 1$ & $1.96: 1$ & $0.67: 1$ & $2.24: 1$ \\
\hline & 2017 & $3.45: 1$ & $20.31: 1$ & $0.23: 1$ & $3.05: 1$ & $0.18: 1$ & $2.47: 1$ \\
\hline & 2016 & $2.90: 1$ & 19.09:1 & $0.21: 1$ & $2.94: 1$ & $0.04: 1$ & $2.78: 1$ \\
\hline Liquidity & 2015 & $3.28: 1$ & 16.80:1 & $0.60: 1$ & $3.20: 1$ & $0.18: 1$ & $7.54: 1$ \\
\hline II. & 2014 & $3.46: 1$ & $20.21: 1$ & $0.43: 1$ & $3.24: 1$ & $0.80: 1$ & 8.09:1 \\
\hline & 2013 & $2.26: 1$ & 23.91:1 & $0.58: 1$ & $2.62: 1$ & $0.69: 1$ & $2.43: 1$ \\
\hline & 2017 & $3.56: 1$ & 20.61:1 & $0.29: 1$ & $3.16: 1$ & $0.20: 1$ & $2.87: 1$ \\
\hline & 2016 & $3.04: 1$ & 19.32:1 & $0.25: 1$ & $3.00: 1$ & $0.08: 1$ & $3.13: 1$ \\
\hline Liquidity & 2015 & $3.39: 1$ & 16.95:1 & $0.69: 1$ & $3.31: 1$ & $0.20: 1$ & $8.28: 1$ \\
\hline III.. & 2014 & $3.62: 1$ & $20.42: 1$ & $0.53: 1$ & $3.33: 1$ & $0.83: 1$ & $8.77: 1$ \\
\hline (EUR:EUR) & 2013 & $2.40: 1$ & $24.30: 1$ & $0.76: 1$ & $2.77: 1$ & $0.69: 1$ & $2.34: 1$ \\
\hline & 2017 & 4.71 & 8.97 & 68.31 & 7.06 & 16.45 & 14.94 \\
\hline & 2016 & 5.44 & 8.72 & 36.29 & 3.53 & 21.86 & 18.27 \\
\hline Stock & 2015 & 5.39 & 6.42 & 30.42 & 7.17 & 8.26 & 19.34 \\
\hline turnover & 2014 & 5.42 & 9.02 & 56.26 & 5.41 & 12.52 & 24.61 \\
\hline & 2013 & 6.07 & 13.72 & 57.54 & 13.22 & 16.56 & 41.18 \\
\hline & 2017 & 76.08 & 96.32 & 87.54 & 56.16 & 13.74 & 85.42 \\
\hline & 2016 & 75.68 & 95.70 & 88.53 & 55.04 & 12.19 & 83.86 \\
\hline & 2015 & 74.83 & 95.35 & 89.86 & 58.30 & 13.43 & 83.11 \\
\hline
\end{tabular}




\begin{tabular}{|c|c|c|c|c|c|c|c|}
\hline \multirow{2}{*}{$\begin{array}{c}\text { Self- } \\
\text { funding } \\
(\%)\end{array}$} & 2014 & 75.08 & 95.75 & 84.22 & 55.54 & 14.57 & 81.66 \\
\hline & 2013 & 74.862 & 97.21 & 85.61 & 51.33 & 8.96 & 76.03 \\
\hline \multirow{5}{*}{$\begin{array}{c}\text { ROA } \\
(\%)\end{array}$} & 2017 & -1.17 & 3.52 & -1.77 & 1.53 & -2.28 & -0.85 \\
\hline & 2016 & -2.02 & 2.72 & -3.03 & -2.81 & -2.06 & -2.00 \\
\hline & 2015 & -.2 .26 & 3.65 & -2.00 & 3.21 & -2.12 & -0.31 \\
\hline & 2014 & -2.03 & 2.88 & -2.37 & 1.82 & 5.25 & -0.79 \\
\hline & 2013 & -2.10 & 1.49 & -2.22 & 3.78 & 3.11 & 0.68 \\
\hline \multirow{5}{*}{$\begin{array}{c}\text { ROE } \\
(\%)\end{array}$} & 2017 & -1.55 & 3.66 & -2.02 & 2.73 & -16.64 & -1.00 \\
\hline & 2016 & -2.67 & 2.84 & -3.43 & -5.11 & -16.93 & -2.39 \\
\hline & 2015 & -3.03 & 3.82 & -2.22 & 5.52 & -15.81 & -0.37 \\
\hline & 2014 & -2.70 & 3.00 & -2.81 & 3.27 & 36.04 & -0.97 \\
\hline & 2013 & -2.81 & 1.53 & -2.59 & 7.36 & 34.78 & 0.89 \\
\hline \multirow{5}{*}{$\begin{array}{c}\text { ROS } \\
(\%)\end{array}$} & 2017 & -15.06 & 19.42 & -146.63 & 2.65 & -110.91 & -13.79 \\
\hline & 2016 & -30.17 & 17.77 & -253.36 & -5.86 & -84.71 & -35.59 \\
\hline & 2015 & -35.93 & 24.42 & -89.44 & 6.42 & -65.67 & -5.24 \\
\hline & 2014 & -32.57 & 21.72 & -179.97 & 3.84 & 242.87 & -17.99 \\
\hline & 2013 & -34.71 & 12.01 & -221.27 & 8.52 & 222.94 & 16.83 \\
\hline
\end{tabular}

Source: authors

Within the sample, the only Košice Airport generated net profits in all analysed years, the airport recorded the stable and high values of self-funding, while all liquidity ratios were above the recommended thresholds. The high values of liquidity ratios recorded by Košice Airport were determined particularly by the values of bank accounts. Whether this is a matter of Košice Airport being allied through the ownership with Vienna Airport cannot be excluded in this regard. The capital airport of the Slovak Republic, Bratislava Airport, generated losses in all analysed years, liquidity ratios were recorded at acceptable levels; self-funding ratios were recorded as relatively stable, however, at lower levels if we compare them with the respective ratios of Košice Airport. Sliač Airport which is the airport with common military and civil operation recorded net profits almost in all analysed years, except for 2016; the satisfactory values of liquidity ratios; however, self-funding ratios were low, slightly more than $50 \%$, what may indicate some risks in the future. Žilina Airport recorded extremely low values of all liquidity ratios, extremely low values of self-funding and the worst values of profitability within 2015 and 2017 years among all airports analysed. The case of Žilina Airport which recorded return on sales $242.87 \%$ in 2014 and $222.94 \%$ in 2013 (both values are positive), documents how the elements of "other operating revenues", impacted on the net profit results of the airport. Regarding the results of financial analysis ex-post, Poprad-Tatry Airport is positioned among loss-making Slovak airports since 2014, however with the satisfactory values of self-funding ratios. Piešt'any Airport recorded losses within the analysed period, liquidity ratios did not reach generally recommended values. Two Slovak airports (Žilina Airport and Piešt'any Airport) may be rated as financially jeopardized due to the generation of extreme losses, and the values of loans against the losses, in the case of Žilina airports self-funding ratios are also threatening. Just these airports suffered from ownership and governance changes as Novák Sedláčková and Švecová (2018) discussed in detail.

The financial analyses of six Slovak airports, which are designed to public international commercial operation, revealed the most of Slovak airports as loss-making entities in the long-term, except of partially privatized Košice Airport and Sliač Airport, which is managed and operated in cooperation with the Ministry of Defence, with an 
agreement specifying the shared use of airport infrastructure and operations (Kazda et al., 2017).

\section{Discussion and conclusions}

When assessing the results of our analyses, several questions may be launched into discussion. As the analyses showed, the only partially privatised Košice Airport may be labelled as profit making airport in the Slovak Republic in the analysed five years period. However, it is not so easy to isolate subjective and endogenous factors represented by such issues as ownership, management, etc. from exogenous ones which could impact on profitability. Just in terms of exogenous factors, Košice Airport is exceptional in comparison with the other Slovak airports, as Košice Airport's competition status is relatively different, and the airport may exploit more the power of local monopoly in several O-D markets with air services. On the other hand, we cannot negate that the privatisation of Košice Airport also could play some role in the P/L result of Košice Airport. The relatively good financial position of Sliač Airport as profit making entity may be partially argued by the common civil/military operation of the airport contributing to the good $\mathrm{P} / \mathrm{L}$ results.

At national level, the Slovak Republic was not very agile in the state aid issues towards its airports, what is sharply contrasting with an approach taken by other member states of the EU which actively participated in the public consultation before the adoption of Aviation Guidelines 2014 and subsequently notified state aids to airports. It may at least indicate that not all new member countries of the European Union will be sufficiently prepared to become a part of the single aviation market of the EU and exploit all eligible tools within their national airport policies. This shows that there are various national airport policies of member countries in terms of their efficiency and readiness.

Our finding about the majority of Slovak (regional) airports as loss making entities partially affirms the European Parliament's statement about the existence of regional lossmaking airports within the EU, on the other hand it is questionable whether this fact may be interpreted as the surplus of (such) airports within the EU, taking into account a broader social and economic importance of such airports for surrounding regional economies. In this context we deem that national airport policies of member countries versus transnational airport policy of the EU ought to have clear dividing line and the interface of such policies ought to be ensured better as it is at the present time.

\section{Acknowledgments}

This paper is the output of the project of the Ministry of Education, Science, Research and Sport of the Slovak Republic VEGA 1/0624/18.

\section{References}

1. Abbott, M. (2015). Reform and efficiency of New Zealand's airports. Utilities Policy, 36(C), 1-9.

2. Adler, N. et al. (2013). Small regional airport sustainability: Lessons from benchmarking. Journal of Air Transport management, 33(C), $22-31$. 
3. Barros, C.P. et al. (2013). The efficiency of French regional airports: An inverse B-convex analysis. International Journal of Production Economics, 141( 2), 668674.

4. Bartošová, V., Král’. P. (2017). Methodological framework of financial analysis results objectification in Slovak Republic. Journal of modern accounting and auditing, 13(2), 394-400.

5. Cahill, C. et al. (2017). Commercialisation and airport performance: The case of Ireland's DAA. Journal of Air Transport Management, 59, 155-163.

6. Čepel, M. (2019). Social and Cultural Factors and Their Impact On The Quality Of Business Environment In the SME Segment. International Journal of Entrepreneurial Knowledge, 7(1), 65-73.

7. Červinka, M., Matušková, S. (2018). Are Low Cost Carriers a problem for the management of regional airports? Transportation research procedia 35, 54-63.

8. Copenhagen Economics: Airport Competition in Europe, 2012. (2012) from: http://www.seo.nl/uploads/media/2012-47_Airport_Competition_in_Europe.pdf

9. Dobrovič, J., Kmeco, L., Gallo, P., Gallo jr., P. (2019). Implications of the Model EFQM as a Strategic Management Tool in Practice: A Case of Slovak Tourism Sector. Journal of Tourism and Services 10(18): 47-62

10. Dobruszkes, F. et al. (2017). Hello major airports, goodbye secondary airports? Recent changes in European and US low-cost airline airport choice. Journal of Air Transport Management, 59(C), 50 - 62.

11. European Commission. (2015). An Aviation Strategy for Europe. Communication from the Commission to the European Parliament, the Council, the European Economic and Social Committee of the Regions (SWD(2015) 261 final).

12. European Commission. (2014). Communication from the Communication Guidelines on State Aid to airports and airlines (2014/C 99/03).

13. European Parliament. (2017). European Parliament resolution of 16 February 2017 on An Aviation Strategy for Europe.

14. Fragoudaki, A. et al. (2016). Efficiency and productivity changes in Greek airports during the crisis years 2010 - 2014. Journal of Air Transport Management, 57, $306-315$.

15. Grabowska, M.(2008). The role of the social policy in creating the image of the region. Journal of Scientific Papers ECONOMICS \& SOCIOLOGY, 1(1).

16. Graham, A. (2013). Understanding the low cost carrier and airport relationship: a critical analysis of the salient issues. Tourism management: research, policies, practice, $36,66-76$.

17. Halpern, N., Graham, A. (2016). Performance and prospects of smaller UK regional airports. Journal of Airport Management,11(2), 180 - 201.

18. Kazda, A., Hromádka, M., Mrekaj, B. (2017). Small regional airports operation: unnecessary burdens or key to regional development. Transportation Research Procedia 28, $59-68$.

19. Lian, J.I. - Ronnevik, J. (2011). Airport competition - Regional airports losing ground to main airports. Journal of Transport Geography, 19(1), 85-92.

20. Novák A. Novák Sedláčková, A. (2010). Simulation at the Bratislava Airport after Application of Directive 2009/12/EC on Airport Charges. Transport and Telecommunication, 11(2), 50 - 59.

21. Novák Sedláčková, A., Švecová, D. (2018) The regional airports position within the Slovak Republic: The case study of Pieštany Airport and the proposal of measures for its revitalization. Transportation Research Procedia 35, 209-219. 
22. Reiff, M. (2007). Marketing Study of Letisko Piešt’any, a.s. Košice. Daidalos.

23. Tomová A. (2011) Privatising Bratislava: Small Airport-Big Problem.

24. Tomová, A. et al. (2017). Ekonomika letísk. Žilina: University of Žilina. EDIS. ISBN 9788055412573.

25. Zalai, K. et al. (2013). Finančno-ekonomická analýza podniku. ISBN 9788089393800 .

\section{Brief description of Author/Authors:}

Assoc. prof. JUDr. Alena Novák Sedláčková, PhD.

Air Transport Department, Faculty of Operation and Economics of Transport and Communications, University of Žilina, Univerzitná 1, 01026 Žilina, Slovakia, email:alena.sedlackova@fpedas.uniza.sk. She is responsible for courses of Air Law and Business and Personal Relationships in Civil Aviation. Her research is focused on the legal aspects of aviation, economic regulation of airports, horizontal cooperation of airlines and economics of regional airports under the legal framework of the EU.

\section{Ing. Denisa Švecová}

Air Transport Department, Faculty of Operation and Economics of Transport and Communications, University of Žilina, Univerzitná 1, 01026 Žilina, Slovakia, email:denisa.svecova@fpedas.uniza.sk. The PhD student and her dissertation thesis and research is focused on the economics of regional airports under the legal framework of the EU.

prof. Anna Tomová, CSc.

Air Transport Department, Faculty of Operation and Economics of Transport and Communications, University of Žilina, Univerzitná 1, 01026 Žilina, Slovakia, email:anna.tomova@fpedas.uniza.sk. She has introduced the new courses of Aviation Economics at the Department of Air Transport at University of Žilina. In her research, she focuses on the economics of airlines, airports and air navigation service providers in the context of national and international transport policies. 